\title{
Investigation of the effects of different sulfate types found in seawater on concrete containing microfiber and silica fume
}

https://doi.org/10.21698/rjeec.2020.218

Proceedings Paper

\author{
MURAT SAYDAN*, NEMATULLAH RAHIMI, ESRA YEL, ULKU SULTAN KESKIN
}

Konya Technical University, Engineering and Natural Science Faculty, Civil Engineering Department, Turkey

*Corresponding author (e-mail): msaydan@ktun.edu.tr

\begin{abstract}
Sulfate salts which available in seawater with high concentrations cause the formation of ettringite in hydrated structures which formed as a result of the hydration of cement. On the other hand, ettringite causes excessive volume expansions and eventually leads to cracking of the concrete due to the internal stresses in concrete since it is a large volume mineral structure. In this study, ultrafine cement and silica fume as mineral additive were used together for binder design. Besides, microfiber has been added to the binder systems produced in different proportions. The produced specimens were kept separately in water, in solutions containing $2 \% \mathrm{Na}_{2} \mathrm{SO}_{4}$ and $2 \% \mathrm{MgSO}_{4}$ by weight for 90 days. The compressive strength test was performed at $28^{\text {th }}$ and $90^{\text {th }}$ days on cured specimens. In addition to the compressive strength test, the solution samples were taken from the curing solutions every 10 days and the change of sulfate concentrations was followed in the solutions. According to the results, in $\mathrm{Na}_{2} \mathrm{SO}_{4}$ solution higher compressive strength values were observed up to $66 \mathrm{MPa}$ while strength loss was observed in the specimens cured in the $\mathrm{MgSO}_{4}$ solution. In parallel to this result, the remaining concentrations of $\mathrm{SO}_{4}{ }^{2-}$ ions in the $\mathrm{MgSO}_{4}$ solution were lower than those in the $\mathrm{Na}_{2} \mathrm{SO}_{4}$ solution. It was inferred that in $\mathrm{Na}_{2} \mathrm{SO}_{4}$ solution, the fibers could compensate for the internal stresses. This situation shows that especially the microfiber additive can compensate for the expansion that will occur as a result of ettringite formation, and thus it can help the mechanical stability of the concrete.
\end{abstract}

Keywords: sulfate attack, ultrafine cement, microfibers, sulfate concentration, concrete

\section{INTRODUCTION}

The sulfate $\left(\mathrm{SO}_{4}\right)$ effect is one of the most important durability problems in concrete. $\mathrm{SO}_{4}$, especially in seawater, soil and groundwater, converts the phase from monosulfate (AFm) phase to the tri-sulfate (AFt) phase, which is formed as a result of the hydration process in cement [1-3]. This transformation continues after the hardening of concrete causes volume increase which results in cracking of concrete [4]. Among the aggressive chemicals, $\mathrm{SO}_{4}$ 's are known to be the most aggressive ions affecting the durability of concrete structures [5]. Sodium sulfate $\left(\mathrm{Na}_{2} \mathrm{SO}_{4}\right)$ is one of the main $\mathrm{SO}_{4}$ types in reinforced concrete structures [6]. Although magnesium sulfate $\left(\mathrm{MgSO}_{4}\right)$ and potassium sulfate $\left(\mathrm{K}_{2} \mathrm{SO}_{4}\right)$ are less common, they are more dangerous types of $\mathrm{SO}_{4}$ in terms of their effects on concrete. It is known that $\mathrm{MgSO}_{4}$ is the most aggressive type among $\mathrm{SO}_{4}$ salts [1].

Reinforced concrete elements that are generally attacked by $\mathrm{SO}_{4}$ are foundations, channel concretes, retaining wall concretes, marine pier concretes, and concrete pipes. The effect of $\mathrm{SO}_{4}$ attack can be more destructive especially on pier concretes and concrete pipes because of exposure to many different types of $\mathrm{SO}_{4}$ 's and their simultaneous physical and chemical effects.

The effect of $\mathrm{SO}_{4}$ attack on concrete can be reduced in various ways. One of these measures is the use of low $\mathrm{C}_{3} \mathrm{~A}$ cement. In the ASTM $\mathrm{C} 150$ [7] standard, $\mathrm{C}_{3} \mathrm{~A}$ content is limited to a maximum $8 \%$ for moderately durable concretes and a maximum 5\% for highly durable concretes for $\mathrm{SO}_{4}$ attack. According to EN 1971 , this limit is a maximum 3\% [8]. Also, the $\mathrm{SO}_{4}$ resistance could be increased by reducing the porosity of concrete, using pozzolan (fly ash, silica fume, etc.), and isolating concrete with resistive coating products against $\mathrm{SO}_{4}$ [9]. The purpose of this paper is to investigate the $\mathrm{SO}_{4}$ resistance of the mixtures prepared with ultra-fine cement (DMFC-800), silica fume, and microfiber experimentally. While forming the mixtures, it is aimed to increase the impermeability by using ultra-fine cement and 
silica fume. Moreover, microfibers were used to reduce micro-cracks during the expansion

\section{MATERIALS AND METHODS}

In the mixtures, the limestone aggregates of $0-4$ mm (Type 1), 4-11.2 mm (Type 2), and 11.2$22.4 \mathrm{~mm}$ (Type 3 ) were used. The granulometry curves of the aggregates were presented in Figure 1. The ultra-fine cement (DMFC-800) and silica fume (SF) were used as binders. The microfibers (MFs) from KORDSA co. were added to the mixtures in $600 \mathrm{gr} / \mathrm{m}^{3}$ dosage to process.

reduce the expansion cracks. The polycarboxylate-ether-based high range waterreducing and retarding admixture (WRA) was used at $1 \%$ by mass of the binder. The water/binder ratio in all mixtures was kept constant at 0.65 . The specifications of the used materials are given in Table 1-3, and the mixture proportions are given in Table 4.
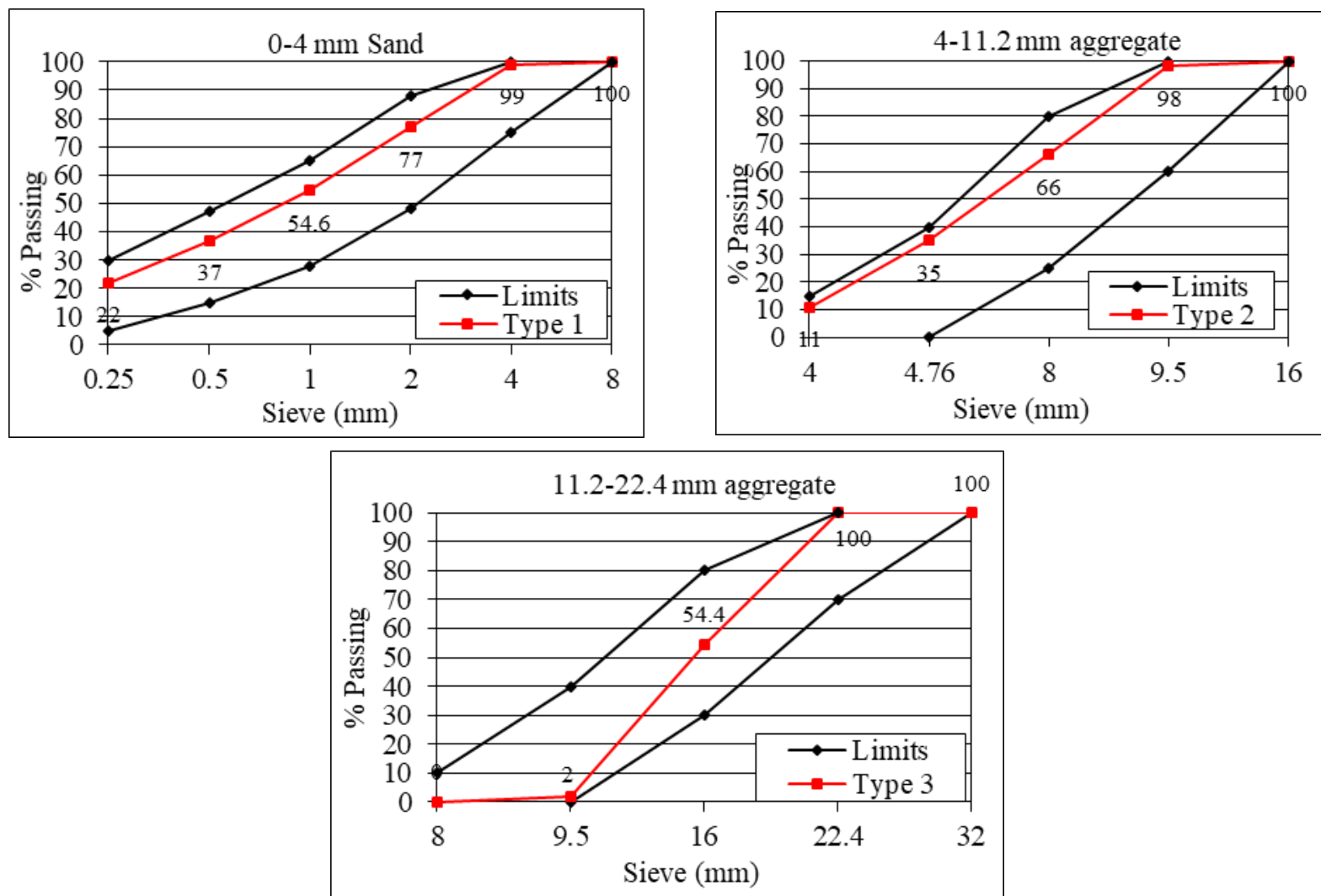

Fig. 1. Granulometry Curves of the Aggregates (Limits are taken from TS 802)

Table 1. Physical and mechanical properties of DMFC-800 ultra-fine cement

\begin{tabular}{c|cc}
\hline Analysis & Tests & Value \\
\hline \multirow{3}{*}{ Physical } & Density $\left(\mathrm{g} / \mathrm{cm}^{3}\right)$ & 3.12 \\
& Blaine $\left(\mathrm{m}^{2} / \mathrm{kg}\right)$ & $\geq 600$ \\
& Color & Grey \\
& Initial setting time $(\mathrm{min})$ & 120 \\
& Final setting time $(\mathrm{min})$ & 150 \\
\hline \multirow{2}{*}{ Compressive } & 3 Days $(\mathrm{MPa})$ & 26 \\
Strength & 7 Days $(\mathrm{MPa})$ & 47 \\
& 28 Days $(\mathrm{MPa})$ & 61 \\
\hline
\end{tabular}


Table 2. XRF analysis results and physical specifications of silica fume.

\begin{tabular}{lccc}
\hline & XRF Analysis (\%) & \multicolumn{2}{c}{ Physical Specifications } \\
\hline $\mathrm{SiO}_{2}$ & 89.94 & Density & $5.21 \mathrm{~g} / \mathrm{cm}^{3}$ \\
$\mathrm{Cr}_{2} \mathrm{O}_{3}$ & 0.38 & Blaine $\left(\mathrm{m}^{2} / \mathrm{kg}\right)$ & 14200 \\
$\mathrm{Fe}_{2} \mathrm{O}_{3}$ & 0.41 & Color & Dark Grey \\
$\mathrm{Al}_{2} \mathrm{O}_{3}$ & 0.83 & & \\
$\mathrm{CaO}$ & 2.53 & & \\
$\mathrm{MgO}$ & 7.68 & & \\
$\mathrm{C}$ & 1.22 & & \\
$\mathrm{~S}$ & 0.923 & & \\
Loss of Ign. & 2.96 & & \\
\hline
\end{tabular}

Table 3. Specifications of Kratos microfibers.

\begin{tabular}{ll}
\hline Physical Properties & Specifications and Values \\
\hline Fiber class & EN 14889-2 class 1 \\
Material & Polyamide 6.6 \\
Density $\left(\mathrm{g} / \mathrm{cm}^{3}\right)$ & 1.14 \\
Length $(\mathrm{mm})$ & 12 \\
Tensile Strength $(\mathrm{MPa})$ & 970 \\
Melting Temperature $\left({ }^{0} \mathrm{C}\right)$ & 260 \\
\hline
\end{tabular}

Table 4. Mixing proportions according to TS 802

\begin{tabular}{|c|c|c|c|c|c|c|c|c|c|}
\hline \multirow[b]{2}{*}{$\begin{array}{l}\text { Specimen } \\
\text { No }\end{array}$} & \multicolumn{3}{|c|}{ Aggregate $\left(\mathrm{kg} / \mathrm{m}^{3}\right)$} & \multirow[b]{2}{*}{$\begin{array}{c}\text { DMFC- } \\
800 \\
\left(\mathrm{~kg} / \mathrm{m}^{3}\right)\end{array}$} & \multicolumn{2}{|c|}{ Silica Fume } & \multirow[b]{2}{*}{$\begin{array}{l}\text { Water } \\
\left(\mathrm{L} / \mathrm{m}^{3}\right)\end{array}$} & \multirow[b]{2}{*}{$\begin{array}{l}\text { Micro- } \\
\text { fiber } \\
\left(\mathrm{kg} / \mathrm{m}^{3}\right)\end{array}$} & \multirow[b]{2}{*}{$\begin{array}{c}\text { WRA } \\
\%\end{array}$} \\
\hline & 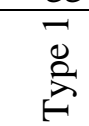 & 总 & $\begin{array}{l}m \\
\infty \\
\infty \\
k\end{array}$ & & $\left(\mathrm{~kg} / \mathrm{m}^{3}\right)$ & $\%$ & & & \\
\hline SD0-B & 858 & 429 & 429 & 265 & 0 & 0 & 170 & 0 & 0.8 \\
\hline SD5-B & 860 & 430 & 430 & 252 & 13 & 5 & 170 & 0 & 0.8 \\
\hline SD10-B & 863 & 431 & 431 & 238 & 26 & 10 & 170 & 0 & 0.8 \\
\hline SD15-B & 865 & 432 & 432 & 225 & 40 & 15 & 170 & 0 & 0.8 \\
\hline SD0-kmB & 858 & 429 & 429 & 265 & 0 & 0 & 170 & 0.6 & 1 \\
\hline SD5-kmB & 860 & 430 & 430 & 252 & 13 & 5 & 170 & 0.6 & 1 \\
\hline SD10-kmB & 863 & 431 & 431 & 238 & 26 & 10 & 170 & 0.6 & 1 \\
\hline SD15-kmB & 865 & 432 & 432 & 225 & 40 & 15 & 170 & 0.6 & 1 \\
\hline
\end{tabular}

The mixing ratios for concrete samples were calculated according to TS 802 [10] standard for $\mathrm{C} 25 / 30$ Class. According to the mixing ratios given in Table 4, the fresh concrete samples were prepared with PAN type mixer (Fig. 2a) and three cube specimens were prepared in molds in $150 * 150 * 150$ dimensions for each group and age (Fig. 2b). Nine specimens were produced from each group to expose the tap water (reference test), $\mathrm{Na}_{2} \mathrm{SO}_{4}$ solution, and $\mathrm{MgSO}_{4}$ solutions cures.
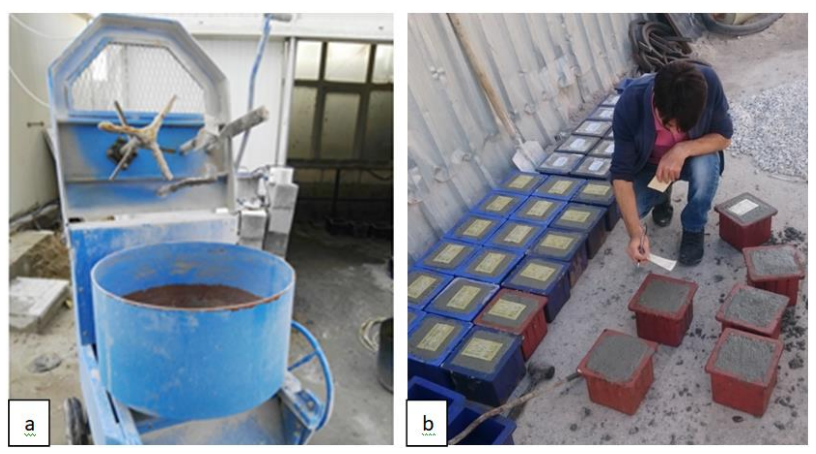

Fig. 2. a) Pan type mixer, b) Molding of specimens 
For the $\mathrm{SO}_{4}$ attack test, the magnesium-sulfateheptahydrate $\left(\mathrm{MgSO}_{4} \cdot 7 \mathrm{H}_{2} \mathrm{O}\right)$ and sodiumsulfate-anhydrate $\left(\mathrm{Na}_{2} \mathrm{SO}_{4}\right)$ from Merck co. were used to prepare the solution. The prepared concrete specimens were separately immersed in $\mathrm{Na}_{2} \mathrm{SO}_{4}$ and $\mathrm{MgSO}_{4}$ solutions of $2 \%$ concentrations for 28 and 90 days (Fig. 3). The $50 \mathrm{~mL}$ solution samples were taken per 10 days to analyze the $\mathrm{SO}_{4}$ concentrations while the specimens were being immersed in solutions. The concentration analyses were carried out according to Standard Methods, Method no 8051 [11] using a turbidimetric technique. In the experiment, $\mathrm{Ba}^{2+}$ ion was added to the sample and mixed with a magnetic stirrer. The concentration of $\mathrm{SO}_{4}$ ions was read in 5 minutes after the experiment started on the $\mathrm{HACH}$ DR/4000U spectrophotometer.

Lastly, the CS test was conducted on cured and reference specimens to determine the mechanical strength of the concrete samples.
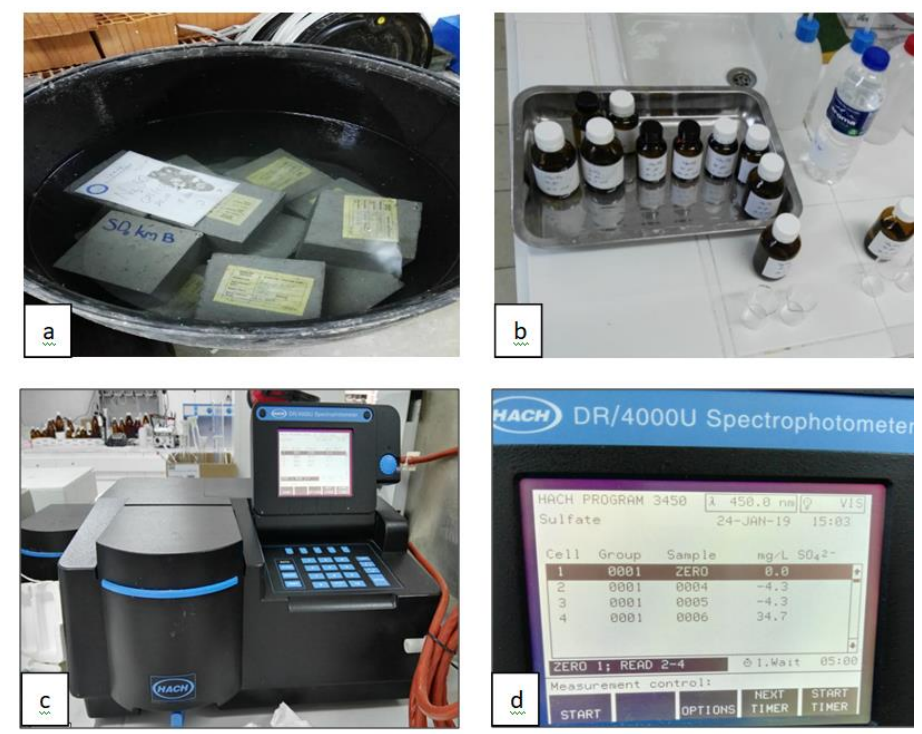

Fig. 3. a) Concrete curing in $\mathrm{SO}_{4}{ }^{2-}$ solutions, b) Sampling from $\mathrm{SO}_{4}$ solutions, c, d) $\mathrm{HACH}$ DR/4000U spectrophotometer

\section{RESULTS AND DISCUSSION}

\section{Compressive strength results}

The physical appearances of the specimens were examined at the end of the 28-day and 90day curing periods (Fig. 4a). When looking at the specimens, neither color change nor crack was observed on the surfaces of the specimens cured in $\mathrm{Na}_{2} \mathrm{SO}_{4}$ solution (Fig. 4b). On the contrary, white spots and foams occurred on the surface of the specimens cured in $\mathrm{MgSO}_{4}$ solution (Fig. 4c, 4d). After visual inspections, the CS test was performed on the specimens. The test results are given in Figures 5 and 6.

As the dosage of SF admixture increased, CS of the reference samples increased both in the presence and absence of MFs. In the reference samples, MFs caused a further increase in CS only up to $10 \%$. The highest CS, 64.2 MPa, was observed in SD15-kmB specimen containing both MFs and SF, whereas, the lowest CS, 53.7 $\mathrm{MPa}$, was observed for the reference specimens without admixtures. In the literature, McCarthy and Dyer [12] indicated that SF admixtures resulted in 29.1-46.8 $\mathrm{MPa}$ CS for various types of concrete samples and they reported that the performance is very much more dependent on the type of pozzolanic material used. The CS values of both the reference concrete and the specimens with SF admixture obtained in this study were much higher than the levels reported by McCarthy and Dyer [12]. 


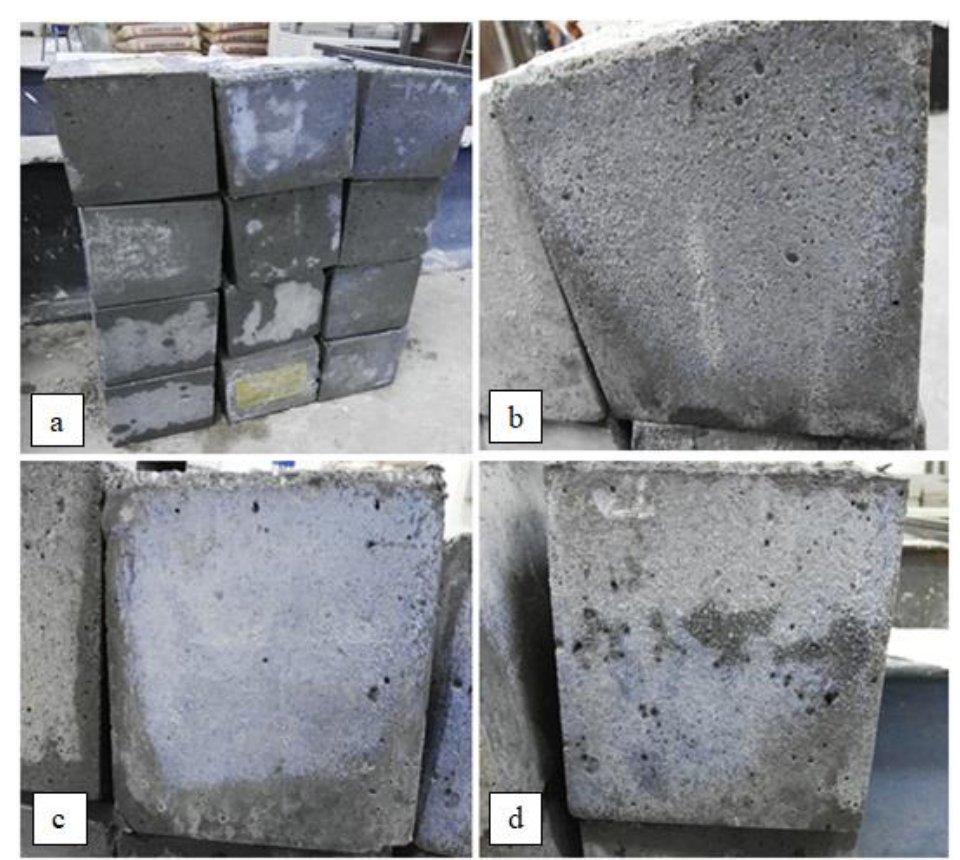

Fig. 4. The cured specimens: a, b) $\mathrm{Na}_{2} \mathrm{SO}_{4}$ curing specimens; c, d) $\mathrm{MgSO}_{4}$ curing specimens

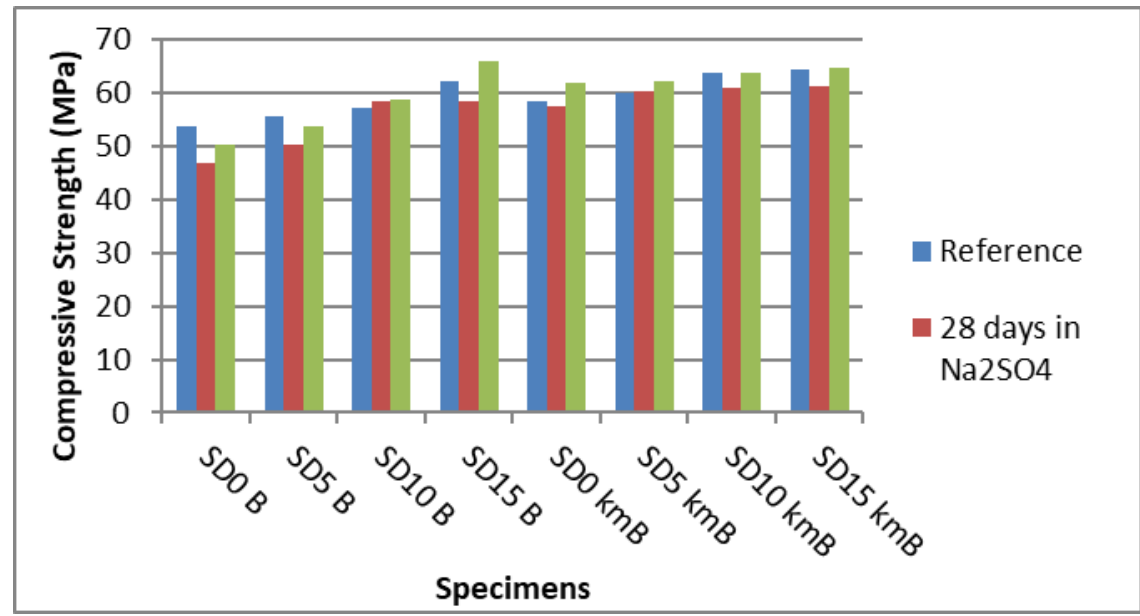

Fig. 5. CS test results for the specimens cured in $\mathrm{Na}_{2} \mathrm{SO}_{4}$ solution

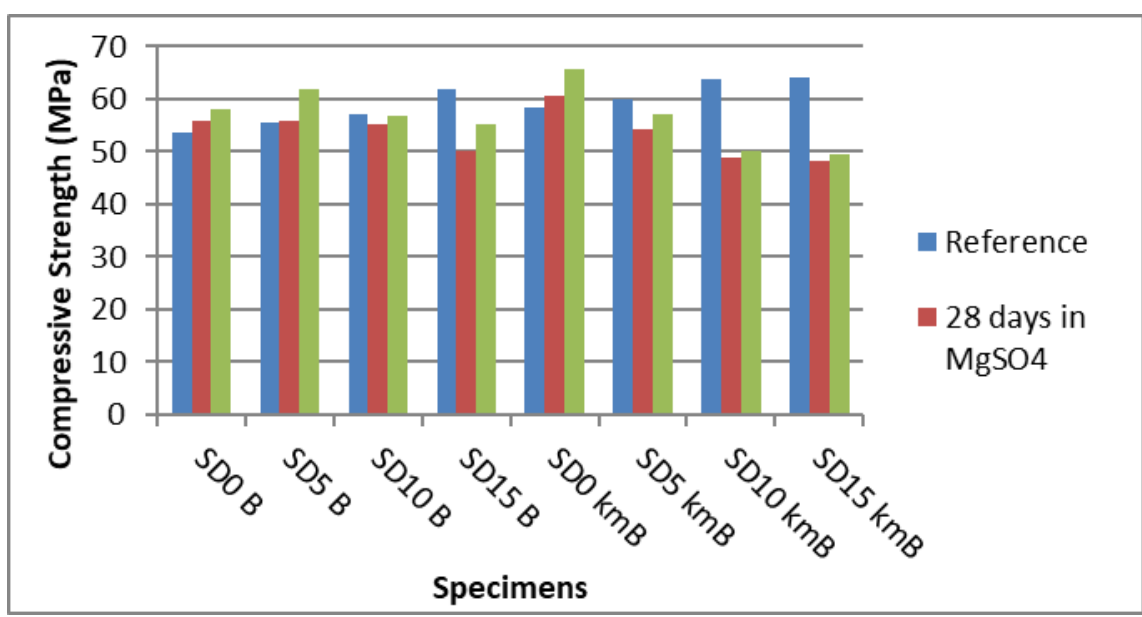

Fig. 6. $\mathrm{CS}$ test results for the specimens cured in $\mathrm{MgSO}_{4}$ solution

The specimens cured in $\mathrm{Na}_{2} \mathrm{SO}_{4}$ solutions and tap water (reference) for 28 days presented similar CS results. At SF dosages greater than or equal to $10 \%, 90$ days CS was higher than the reference samples in $\mathrm{Na}_{2} \mathrm{SO}_{4}$ curing solutions (Fig. 5). Similarly, when MFs were 
used together with SF, the resultant 90 days CS of the samples cured in $\mathrm{Na}_{2} \mathrm{SO}_{4}$ were approximately equal or slightly higher than CS of the reference samples which were cured in tap water without $\mathrm{SO}_{4} .15 \% \mathrm{SF}$ admixture in the $\mathrm{Na}_{2} \mathrm{SO}_{4}$ without MF resulted in the highest CS as $66 \mathrm{MPa}$ which was $50 \mathrm{MPa}$ for the reference. Whereas, CS values of the samples including MFs increased from $61.6 \mathrm{MPa}$ to $64.4 \mathrm{MPa}$. These indicated that MF is buffering the $\mathrm{SO}_{4}$ reaction and cause all types of concrete specimens (i.e., reference, 28 days and 90-days concrete) to have CS levels close to each other in $\mathrm{Na}_{2} \mathrm{SO}_{4}$. However, the effect of SF dosage on $\mathrm{CS}$ with SF admixture alone is more belligerent without MFs (Figure 5). $\mathrm{Na}_{2} \mathrm{SO}_{4}$ is known to react with $\mathrm{SiO}_{2}$ to form sodium silicate which is the mixture of the metasilicate and has a wide variety of uses, including the formulation of cement. Basic $\mathrm{pH}$ ranges and the presence of carbon may enhance these reactions and helps to obtain higher CS [13, 14]

On the other hand, white spots and deteriorations seen on the surface of the concrete specimens were indicated the formation of ettringite. The ettringite forms by the reaction of $\mathrm{SO}_{4}$ ions which coming from the external environment (seawater, groundwater, etc.) with the products formed as a result of cement hydration and in the presence of a high amount of water. This reaction causes large volume increases. Sims, et al. reported that tests alternatively using $\mathrm{Na}_{2} \mathrm{SO}_{4}$ or $\mathrm{MgSO}_{4}$ produce different results for each concrete mix, and $\mathrm{MgSO}_{4}$ is usually considered to be more aggressive, although exceptions have been reported [4]. Being consistent with this

\section{Concentration changes in the $\mathrm{SO}_{4}$ solutions}

The changes of curing solution $\mathrm{SO}_{4}$ concentrations with curing time were indicated in Figure 7 for both $\mathrm{MgSO}_{4}$ and $\mathrm{Na}_{2} \mathrm{SO}_{4}$ solutions. For both solutions, $\mathrm{SO}_{4}{ }^{2-}$ ion was absorbed more rapidly in the first 30 days of curing, and after 40 days, $\mathrm{SO}_{4}$ absorption almost finished. The $\mathrm{SO}_{4}{ }^{2-}$ ion of $\mathrm{MgSO}_{4}$ solution was absorbed by the specimens about $70 \%$, which was more than SO4 absorption from $\mathrm{Na}_{2} \mathrm{SO}_{4}$, which was around $40 \%$. Depending on the positions of $\mathrm{Na}$ and $\mathrm{Mg}$ elements in the periodic table, there are some differences in their chemical structures and inference, in this study, when the $\mathrm{SO}_{4}$ in the curing medium is in the form of $\mathrm{MgSO}_{4}$, the findings were completely different as compared to the results of $\mathrm{Na}_{2} \mathrm{SO}_{4}$ curing medium (Fig. 6). For example, 28-days and 90-days CS values were decreasing with SF dosage, both with MFs and without MFs in case of $\mathrm{MgSO}_{4}$ curing. The CS of the specimens without MF were higher than those of the MF reinforced specimens. However, when MF admixture was used alone, without SF, high CS was achieved as $65.6 \mathrm{MPa}$ in $\mathrm{MgSO}_{4}$ in 90 days. This value can be considered as approximately equal to the highest $\mathrm{CS}$ achieved in $\mathrm{Na}_{2} \mathrm{SO}_{4}$ curing solution (Fig. 5 and 6). $\mathrm{MgSO}_{4}$ has a more far-reaching action than other $\mathrm{SO}_{4}$ 's and decomposes the hydrated calcium silicates in addition to reacting with the aluminates and calcium hydroxide [15].

Obe, et al. has stated that the contact of $\mathrm{Na}_{2} \mathrm{SO}_{4}$ and $\mathrm{MgSO}_{4}$ with concrete structures can be a matter of some concern, as the reactions between $\mathrm{SO}_{4}$ 's and hydrated cement compounds result in volume increase and build-up of internal stresses, leading to the breakdown of structures [16]. McCarthy and Dyer revealed that $\mathrm{MgSO}_{4}$ attack is considered to be more severe than that of $\mathrm{Na}_{2} \mathrm{SO}_{4}$ [12]. One feature of this form of attack is the deposition of a double layer composed of brucite and gypsum, followed by several internal layers of gypsum. The formation of the double layer is not necessarily detrimental, since it protects the surface of concrete and mortar from further ingress of $\mathrm{SO}_{4}$, potentially limiting deterioration.

compound properties. $\mathrm{Mg}$ has a larger nuclear charge and smaller atoms than $\mathrm{Na}$, therefore, ionization and electrode potential as well as hydration energy of $\mathrm{Mg}$ are higher than $\mathrm{Na}$. $\mathrm{Na}_{2} \mathrm{SO}_{4}$ is unreactive toward most oxidizing or reducing agents. It is a typical electrostatically bonded ionic salt with a solubility of $13.9 \mathrm{~g} / 100$ $\mathrm{mL}$ whereas the solubility of $\mathrm{MgSO}_{4} \cdot 7 \mathrm{H}_{2} \mathrm{O}$ is $113 \mathrm{~g} / 100 \mathrm{~mL}$, therefore, it is clear that as the water solubility increases, the $\mathrm{SO}_{4}$ ion in the solution become more available to the concrete to absorb under the alkaline conditions in the first days of the hydration. When the concrete 
specimen gaining strength, $\mathrm{SO}_{4}$ absorption of concrete stops. Consequently, no more $\mathrm{SO}_{4}$ absorption into the structure occurs. This is the reason that $\mathrm{SO}_{4}$ concentration in curing water remained almost constant after 40 days.

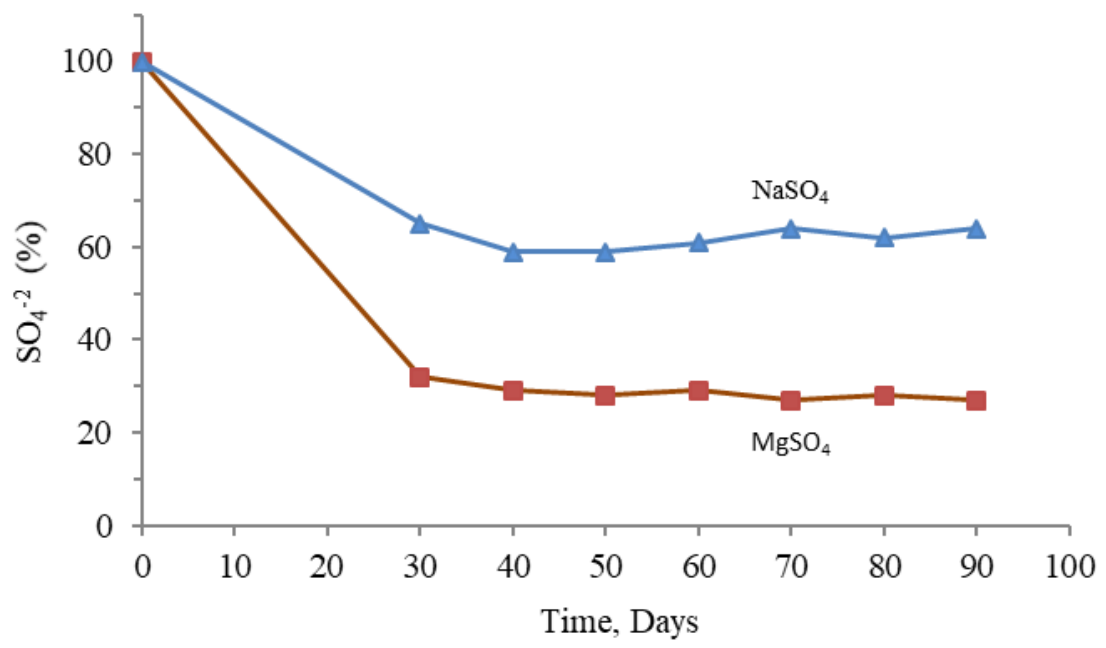

Fig. 7. Change of $\mathrm{SO}_{4}$ concentration with time in curing solutions

\section{CONCLUSIONS}

In this study, the $\mathrm{SO}_{4}$ effect in concrete was investigated on the produced specimens by using fine-grained cement with $\mathrm{SF}$ and $\mathrm{MF}$ additives in different proportions. According to the results obtained, SF additive the combination of silica fume and microfiber additives increased the CS values of specimens cured in $\mathrm{Na}_{2} \mathrm{SO}_{4}$.

It can be seen from the results that $\mathrm{MgSO}_{4}$ has a greater negative effect on the $\mathrm{CS}$ value than that of $\mathrm{Na}_{2} \mathrm{SO}_{4}$. This situation is compatible with the literature. At the same time, the decrease in the concentration of $\mathrm{SO}_{4}$ ions in $\mathrm{MgSO} 4$ solution confirms this situation.

Moreover, the concentration of $\mathrm{SO}_{4}$ ions initially increased rapidly in concrete for the first 30 days, and then the rate of increase gradually decreased.

\section{ACKNOWLEDGEMENTS}

The authors are most grateful to the Bureau of Scientific Research Projects (BAP), in Konya

\section{REFERENCES}

[1] NEVILLE, A. M., Properties of concrete, Longman London, 1995.

[2] TAYLOR, H. F., Cement chemistry, Thomas Telford London, 1997.

[3] BAI, J., Sustainability of construction materials, Elsevier, 2009, p. 239-253.
The formation of ettringite in pores increased significantly which reduced the permeability of the concrete and caused less solution to enter in it.

The most important result indicated by this study is the successful bearing capacity of microfiber additives against the internal stresses formed as a result of the expansions and ettringite formation due to $\mathrm{Na}_{2} \mathrm{SO}_{4}$. However, these additives cannot meet the internal stresses caused by $\mathrm{MgSO}_{4}$. This situation shows that $\mathrm{MgSO}_{4}$ causes much more ettringite formation and expansion in concrete than $\mathrm{Na}_{2} \mathrm{SO}_{4}$. Therefore, it can be concluded that $\mathrm{SO}_{4}$ is an effective ion as an environmental effect on the concrete, but the type of cation bonded to $\mathrm{SO}_{4}$ anion is determining whether that effect is positively or negatively.

Technical University, Turkey for financially supporting this study under grant no 18201096.

[4] SIMS, I., LAY, J., FERRARI, J., Concrete Aggregates, Chapter 15 in: Hewlett, P.C. Liska, M.(eds), Lea's Chemistry of Cement \& Concrete (Fifth Edition), ButterworthHeinemann (Elsevier), Oxford, 2019, p. 699778. 
[5] ZHAO, G., LI, J., SHAO, W., Constr. Build. Mater., 181, 2018, p. 49

[6] INGHAM, J., Geomaterials under the microscope: a colour guide, CRC Press, 2010.

[7] ASTM C150 / C150M-20, Standard Specification for Portland Cement, ASTM International, West Conshohocken, PA, 2020, www.astm.org.

[8] SANJUAN M., ARGIZ C., Mater. Construcc., 62, no. 307, 2012, p. 425

[9] PANESAR, D. K., Developments in the Formulation and Reinforcement of Concrete, Elsevier, 2019, p. 55-85.

[10] TS 802: Concrete mixture design calculation principles, Ankara, Turkish Standards Institute, 2016 [in Turkish].

[11] APHA, AWWA, WEF, Standard Methods for the examination of water and wastewater,
American Public Health Association, Washington DC, USA, 2005.

[12] MCCARTHY, M. J., DYER, T. D., Lea's Chemistry of Cement and Concrete (Fifth Edition), Butterworth-Heinemann (Elsevier), Oxford, 2019, p. 363-467.

[13] LU, Y., 2008, US patent no: US 2008/0199385 A1.

[14] JACOBSON, N. S., Oxid. Met., 31, no. 12, 1989, p. 91 .

[15] EGLINTON, M., Lea's chemistry of cement and concrete, (Fourth Edition), Eds. Hewlett, P.C., Elsevier Ltd., Oxford, 2003, p. 299.

[16] RAVINDRA, K., OBE, D., DE BRITO, J., MANGABHAI, R., LYE, C. Q., Sustainable construction materials: copper slag, Woodhead Publishing, 2017, p. 87-164. 